\title{
Research on the Influence of Value Co-creation Practices on Oppositional Brand Loyalty
}

\author{
Hanyi Lou \\ School of Management, Shanghai University, 20 Chengzhong Road, Shanghai 201800, China
}

\begin{abstract}
Oppositional brand loyalty means that customers express loyalty to their preferred brand by opposing those rival brands and their consumers. Research on oppositional brand loyalty helps to foster loyal customers and has a great impact on brand equity. The research of oppositional brand loyalty is in its infancy and requires deeper investigation. Based on self-categorization theory, this paper analyzes the effect of value co-creation practices on oppositional brand loyalty and the mechanism of brand community identification and implicit self-esteem in the context of brand community. It is expected that this paper will not only inspire similar research, but also provide reference for enterprises to strengthen the building of brand relationship through brand community.

Keywords: Value co-creation practices, Oppositional brand loyalty, Brand community identification, Implicit self-esteem
\end{abstract}

DOI: $10.7176 / \mathrm{EJBM} / 11-27-07$

Publication date:September $30^{\text {th }} 2019$

\section{Introduction}

In the development process of enterprise, obtaining and maintaining customers' loyalty to the brand is the key to maintaining rival advantages. Customers will express their support for the preferred brand not only by repurchasing, recommending and so on, but also opposing buying products or services of rival brands, forming confrontational situations with consumers of rival brand, and negatively recommending rival brands to others. This phenomenon is called oppositional brand loyalty, which is to express loyalty to the preferred brand by opposing rival brands and their consumers (Muñiz \& Hamer 2001). Oppositional brand loyalty involves the relationship among customers, the preferred brand and rival brands, which is different from brand loyalty. The research on oppositional brand loyalty is conducive to cultivating loyal customers and promoting the value of brand equity.

The existing research on the factors affecting oppositional brand loyalty is mainly focused on brand, consumer, and situation level. Djedidi (2016) has found that consumers' brand experience affects oppositional brands loyalty. When consumers experience negative incidents of a brand, then they will look for other brands that meet their needs and reject the brand with negative experiences. Yang \& Guo (2017) have found that selfconcept - brand image consistency is positively related to oppositional brand loyalty, and brand attachment plays a full mediating role in the relationship between self-concept - brand image consistency and oppositional brand loyalty. Djedidi (2013) believes that if consumers get access to the negative information of the preferred brand, they will be more active in protecting the preferred brand in order to strengthen the resistance to rival brands in the face of fierce attacks from rival brands. However, there are relatively few studies conducted at brand community level. The brand community provides a platform for the enterprise and consumers to communicate and interact about the brand. It not only meets the needs of enterprise to promote products or services, understand consumers' voices, and maintain relationships with consumers, but also meets consumers' needs for brand information, social and entertainment. The rapid spread of social networking technology provides a new platform for brand community to retain existing consumers and attract new ones (Kietzmann et al. 2011). Brand community based on social media technology has the characteristics of no time limit, no geographical limit, high information transparency, multi-party communication, and has become an important platform for value cocreation practices. In the brand community, consumers can communicate with each other and share their consumption experience. Besides, Marketing managers can listen to consumers and interact with them. Schau et al. (2009) classifies brand community practices into four categories: social networking practice, community engagement practice, impression management practice and brand use practice. These practices realize value cocreation of brand community. Nowadays, product competition is increasingly fierce. How to manage brand community and maintain customers' brand loyalty has become the focus of enterprises.

On the basis of summarizing previous theoretical and empirical research, this paper summarizes the effect of value co-creation practices on oppositional brand loyalty and its mechanism. As the community gradually becomes an important channel for enterprises to build brand relationships, it is expected that this paper will not only inspire similar research, but also provide reference for enterprises to strengthen the building of brand relationship through brand community. 


\section{Relationship between Value Co-creation Practices and Oppositional Brand Loyalty}

\subsection{Oppositional Brand Loyalty}

The concept of oppositional brand loyalty was first proposed by Muñiz \& Hamer (2001), that is, to express loyalty to the preferred brand by opposing rival brands and their consumers. This definition has also been accepted and used by a wide range of scholars.

Brand loyalty shows the harmonious relationship between customers and the brand they identify with, while oppositional brand loyalty also involves rival brands, reflecting the relationship among the three. Accordingly, for rival brands, oppositional brand loyalty is also an anti-consumption behavior. Anti-consumption behavior mainly includes brand avoidance, brand boycott, brand retaliation and so on. There are still significant differences between oppositional brand loyalty and the three. First, the difference between oppositional brand loyalty and brand avoidance is mainly reflected in the way of behavior. Brand avoidance is mainly manifested in not buying products or services of the brand, while oppositional brand loyalty includes some other antagonistic behaviors. Second, the difference between oppositional brand loyalty and brand boycott is mainly reflected in the behavior body. Brand boycott is a social activity, while oppositional brand loyalty is only an individual or collective behavior. Third, the difference between oppositional brand loyalty and brand retaliation is mainly reflected in the behavioral consequence. Brand retaliation is too extreme and may violate moral principles, while oppositional brand loyalty is usually not destructive. Since oppositional brand loyalty involves the interaction among customers, the preferred brand and rival brands, it has more special behavior characteristics and deserves further study.

\subsection{Value Co-creation Practices and Oppositional Brand Loyalty}

Advance of networking and communication technology has brought new opportunities and challenges to relationship marketing, and brand community has received extensive attention from enterprises and researchers. Brand community takes brand as a link to connect consumers who like the same brand, so that this group can communicate and interact constantly with each other to maintain the vitality of the community. With the rapid development of the Internet, customers are creating value while consuming. Customer resources are crucial for brand development. Brand community provides an important platform for value co-creation of customers and the enterprise, in which the enterprise and customers can be win-win through a series of value co-creation practices. Brand researchers agree that in the context of brand community, strengthening brand community and promoting consumer experience can consolidate customer loyalty to the brand. In the brand community, customers gain value from interaction with the brand and other customers through value co-creation practices, which makes them trust and like the brand (Zhou et al. 2012). In the process of value co-creation practices, consumers' perception of brand image is consistent with self-concept, which can promote consumers' affection for the brand. At the same time, this positive perception of the preferred brand can also stimulate negative evaluation and opposition to rival brands (Phillips-Melancon \& Dalakas 2014).

\subsection{The Mediating Role of Brand Community Identification}

\subsubsection{Value Co-creation Practices and Brand Community Identification}

The collective value co-creation process in brand community is mainly driven by a series of practices: social networking practice, community engagement practice, impression management practice and brand use practice. These practices also include specific activities such as welcome, compassion, customization, commercialization and so on (Schau et al. 2009). Through practices in the brand community, consumers can interact continuously and deepen their understanding of the brand. Social capital theory shows that frequent interpersonal communication is conducive to building and strengthening social networking and trustworthy relationships, enhancing cohesion of the brand community (Lee et al. 2012), and thus promoting brand identity (Algesheimer et al. 2005). This paper believes that value co-creation practices promote friendship between consumers through common maintenance of the community. Also, they establish common brand values and common beliefs. What's more, value co-creation practices make them feel that this is their common home, thus strengthening identify of the community.

\subsubsection{Brand Community Identification and Oppositional Brand Loyalty}

Brand community identification not only enables community members to reach a consensus on the preferred brand, but also clarifies the relationship between the preferred brand and rival brands by defining "what brand is not" and "whom community members are not" (Kuo \& Feng 2013). Common awareness is the inner connection that community members feel with each other, as well as the collective sense different from others outside the brand community. Madupu \& Cooley (2010) point out that oppositional brand loyalty will also improve with the increase of common awareness among members of the brand community. Community identification is a kind of emotional dependence and commitment to the community, which in turn affects oppositional brand loyalty. 
2.3.3 The Mediating Role of Brand Community Identification between Value Co-creation Practices and Oppositional Brand Loyalty

Self-categorization theory shows that in group environment, individuals categorize themselves and others as internal and external groups respectively, emphasizing internal consistency for internal groups, while emphasizing external differences for external groups. According to self-categorization theory, brand community identification may be a bridge connecting value co-creation practices and oppositional brand loyalty. By participating in value co-creation practices, consumers can identify "people like me" among others, establish sincere relationships with like-minded people, develop common awareness and promote community identification. This kind of affection for brand community will enhance consumers' favor for the brand, and ultimately form rather high oppositional brand loyalty. Huo et al. (2016) takes the third-party virtual brand community as the research object, and they find that community identification plays a partial mediating role between community participation behaviors and oppositional brand loyalty. Wang (2018) points out that network density, trust reciprocity and common recognition of brand community positively affect oppositional brand loyalty through community identification.

\subsection{The Moderating Role of Implicit Self-esteem}

Implicit self-esteem refers to people's self-assessment through implicit measurement (Greenwald \& Banaji 1995). Gregg \& Sedikides (2010) point out that low implicit self-esteem is conceptualized as a sign of selfvulnerability. The results consistently show that people with low implicit self-esteem are more defensive than those with high implicit self-esteem in threatening environment. Lisjak et al. (2012) argue that when consumers receive negative information about the brand they identify with, people with low implicit self-esteem are more likely to respond defensively. Individuals with low implicit self-esteem may also be threatened and troubled by positive events (Koole \& Dehart 2007). Lisjak et al. (2012) argue that individuals with low implicit self-esteem are more defensive to the brand. When there is certain brand community identification, for individuals with low implicit self-esteem, they will expand support for the preferred brand, but be more disgusted with rival brands, thereby enhancing oppositional brand loyalty. Therefore, implicit self-esteem plays a negative moderating role between brand community identification and oppositional brand loyalty, that is, the lower the implicit selfesteem, the stronger the positive effect of brand community identification on oppositional brand loyalty.

\section{Conclusion}

Based on the relevant theories and empirical studies, this paper believes that value co-creation practices will have certain effect on oppositional brand loyalty, and brand community identification plays a mediating role between value co-creation practices and oppositional brand loyalty. Implicit self-esteem negatively moderates the relationship between brand community identification and oppositional brand loyalty. Accordingly, this paper puts forward the following marketing strategies.

First, realize value co-creation practices of win-win orientation between the enterprise and customers through effective integration of resources. First of all, marketing managers should change the logic of brand marketing and realize that brand value is created by the enterprise and customers together. Only when it is recognized by customers, the brand can be endowed with higher value. Then, enterprises can use brand community as a platform for value co-creation. With the development of Internet technology, communication between people becomes more and more frequent. Enterprises can make full use of the advantages of Internet technology, know the customers' needs, and grasp market trends. The rise of brand community provides an effective way for enterprises to carry out marketing activities. Through the brand community, enterprises can interact with customers at any time, improve the customers' favor to the brand, and lay the foundation for future marketing activities. Finally, in brand community, enterprises can establish incentive mechanism to encourage community members to participate in value co-creation practices actively. Enterprises can build brand equity and create brand value through social networking, community engagement, impression management, brand use and other practical means. Then, it can strengthen the emotional needs of community members, get close to customers, and thus strengthen their oppositional brand loyalty.

Second, improve customers' brand community identification by establishing a harmonious brand community. Enterprises can carry out targeted construction of brand community and create a mutually beneficial community atmosphere. It can make community members establish common brand values, guide them to choose the brand of the enterprise, and strengthen oppositional brand loyalty. On the one hand, for value co-creation practices initiated by enterprises, we should pay attention to the contributions and returns of members in order to improve their satisfaction and identity. For example, members can be rewarded according to their contributions to the activities. On the other hand, community members are encouraged to organize value co-creation activities spontaneously, thereby enhancing inner community identity. For example, members are encouraged to discuss topics and exchange experience in the brand community to provide suggestions for the development of the brand community. Enterprises can also establish corresponding incentive mechanism according to the contributions of 
members to the brand community. In addition, for the uncivilized behaviors in the brand community, marketing managers should deal with them timely and properly, and give appropriate punishments to avoid negative impacts. Creating a harmonious brand community atmosphere helps to enhance the emotional connection between customers and the brand and their identification of the brand community, thus promoting oppositional brand loyalty.

Third, consider the impact of implicit self-esteem on consumer behaviors. Marketing managers should realize that for consumers with different degrees of implicit self-esteem, brand community identification has different effects on oppositional brand loyalty. Marketing managers can adopt different marketing strategies to consumers with different degrees of implicit self-esteem, so as to maximize the oppositional brand loyalty of all members.

\section{References}

Algesheimer, R., Dholakia, U. M., \& Herrmann, A. (2005). The social influence of brand community: Evidence from European car clubs. Journal of Marketing, 69(3), 19-34.

Djedidi, A. (2013). Individual oppositional loyalty: Are loyalty and resistance two sides of the same coin. PostPrint.

Djedidi, A. (2016). Oppositional loyalty of the individual reality: Its antecedents and effects. Post-Print.

Greenwald, A. G., \& Banaji, M. R. (1995). Implicit social cognition: Attitudes, self-esteem, and stereotypes. Psychological Review, 102(1), 4-27.

Gregg, A. P., \& Sedikides, C. (2010). Narcissistic fragility: Rethinking its links to explicit and implicit selfesteem. Self and Identity, 9(2), 142-161.

Huo, C. H., Zhang, Y. D., \& Zhang, X. X. (2016). A study on the influence of user participation in third party virtual brand community on brand loyalty. Consumer Economics, 32(6), 65-70.

Kietzmann, J. H., Hermkens, K., McCarthy, I. P., \& Silvestre, B. S. (2011). Social media? Get serious! Understanding the functional building blocks of social media. Business Horizons, 54(3), 241-251.

Koole, S. L., \& Dehart, T. (2007). Self-affection without self-reflection: Origins, models, and consequences of implicit self-esteem. Frontiers in social psychology: The self.

Kuo, Y. F., \& Feng, L. H. (2013). Relationships among community interaction characteristics, perceived benefits, community commitment, and oppositional brand loyalty in online brand communities. International Journal of Information Management, 33(6), 948-962.

Lee, D., Kim, H. S., \& Kim, J. K. (2012). The role of self-construal in consumers' electronic word of mouth (eWOM) in social networking sites: A social cognitive approach. Computers in Human Behavior, 28(3), 1054-1062.

Lisjak, M., Lee, A. Y., \& Gardner, W. L. (2012). When a threat to the brand is a threat to the self: The importance of brand identification and implicit self-esteem in predicting defensiveness. Personality and Social Psychology Bulletin, 38(9), 1120-1132.

Madupu, V., \& Cooley, D. O. (2010). Antecedents and consequences of online brand community participation: A conceptual framework. Journal of Internet Commerce, 9(2), 127-147.

Muñiz, A. M., \& Hamer, L. O. (2001). Us versus them: Oppositional brand loyalty and the cola wars. Advances in Consumer Research, 28(1), 355-361.

Phillips-Melancon, J., \& Dalakas, V. (2014). Brand rivalry and consumers'schadenfreude: The case of Apple. Services Marketing Quarterly, 35(2), 173-186.

Schau, H. J., Muñiz, A. M., \& Arnould, E. J. (2009). How brand community practices create value. Journal of Marketing, 73(5), 30-51.

Wang, J. (2018). Online brand community social capital, community identification and brand loyalty-The moderating role of platform character. Soft Science, 32(1), 122-125.

Yang, S., \& Guo, S. Y. (2017). A study on the influence of brand attachment on brand oppositional loyalty-based on the adjustment of psychological distance. Consumer Economics, 33(3), 69-76.

Zhou, Z. M., Zhang, Q. Y., Su, C. T., \& Zhou, N. (2012). How do brand communities generate brand relationships? Intermediate mechanisms. Journal of Business Research, 65(7), 890-895. 